\title{
TP KENNISTOETS JUNI 2017
}

Van ieder nummer van TP verschijnt een kennistoets gebaseerd op artikelen uit dat nummer. Deze kennistoets draagt bij aan een betere kennisname van de wetenschappelijke inhoud van het tijdschrift en de toepassing van de vergaarde kennis in de dagelijkse praktijk. Op mijn. bsl.nl kunt u inloggen in uw online-abonnement en deze kennistoets maken. Van de onderstaande $\mathbf{2 0}$ vragen over vijf artikelen in dit juninummer kunt $u$ online een selectie van vijftien vragen beantwoorden.

Terugplaatsen van kroonfragmenten na trauma - door Kayleigh Hesse e.a.

1 Welke factor dient te worden uitgesloten om de kans op verkleuring van MTA na een pulpotomie zo klein mogelijk te maken?

A Contaminatie met speeksel

B Contaminatie met bloed

C Contaminatie met bloed en speeksel

2 Endodontische kanaalsealers hebben de neiging om te verkleuren. Is deze uitspraak juist of onjuist?

A Juist

B Onjuist

3 Een pulpectomie na een kroon-wortelfractuur met pulpa-exponatie in het front is te prefereren boven een pulpotomie als je kijkt naar de kleurstabiliteit van de elementen op langere termijn.

Is deze uitspraak juist of onjuist?

A Juist

B Onjuist

(4) Waarmee moet bij een kroonverlenging palatinaal in het bovenfront rekening worden gehouden?

A Met de nervus infra-orbitalis

B Met de nervus nasopalatinus

C Met de nervus maxillaris

D Met de periradiculaire innervatie

5 Om microlekkage te voorkomen is het van belang dat rondom de preparatie glazuur aanwezig is.

Is deze uitspraak juist of onjuist?

A Juist

B Onjuist

6 Voor het terugplaatsen van een glazuurfragment kan beter geen composietcement worden toegepast.

Is deze uitspraak juist of onjuist?

A Juist

B Onjuist

7 Wanneer heeft het Zwitsers tandheelkundige genootschap (SSO) kwaliteitsstandaarden ontwikkeld m.b.t. behoud van de processus alveolaris en de vitaliteit van de pulpa bij de behandeling van traumata?

A Tussen 1996 en 1998

B Tussen 1986 en 1988

C Tussen 1970 en 1972

Levensduurverlengende restauraties - door dr. Niek Opdam

8 Waarop is palliatieve zorg gericht?

A Op verlichting van de klacht/aandoening, zonder dat hierbij 'genezing' optreedt.

B Op het volledig oplossen van de klacht/aandoening.

C Op het goed informeren van de patiënt over de mogelijke risico's en gevolgen van een behandeling.

9 De letters DSO in de 'DSO-techniek', waarbij in zacht composiet wordt dichtgebeten, staan voor de direct shaping by occlusion.

Is deze uitspraak juist of onjuist?

A Juist

B Onjuist

(10 Wat zijn de risicofactoren voor het falen van restauraties? Meerdere antwoorden zijn mogelijk.

A Een hoog cariësrisico

B Knarsen

C Klemmen

Plan je occlusie voor je begint - door dr. Erik Reukers

(11) Welke van onderstaande uitspraken is juist in het geval van de agenesie van 1 onderincisief?

A De agenesie leidt automatisch tot de noodzaak van een compenserende extractie in de bovenkaak.

De agenesie wordt veroorzaakt door een Angle Klasse II/1 met overjet.

C De agenesie valt vaak pas op als de elementen worden geteld.

D De agenesie kan het beste worden verholpen door het plaatsen van een implantaatgedragen kroon.

(12 Waardoor wordt een mesio-occlusie van de zijdelingse delen gekenmerkt?

A Door een ventrale positie van de ondermolaren ten opzichte van de bovenmolaren.

B Door een ventrale positie van de bovenmolaren ten opzichte van de ondermolaren.

C Door een diepe beet.

D Door een grote overjet.
NWVT beveelt deelname aan deze kennistoets aan

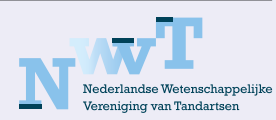

(13) Wat is het ideale moment om een Angle Klasse II met een retrognate onderkaak te corrigeren?

A Als alle melkelementen zijn gewisseld

B Op 12-jarige leeftijd.

C In de groeispurt.

D Als de patiënt volledig is uitgegroeid.

Voedingsadvies dranken: verleiding en realiteit - door dr. Dien Gambon

(14) Welke van de volgende uitspraken is/zijn juist/onjuist?

1 Het WHO-advies is om minimaal $10 \%$ van het totaal aan calorieën uit vrije suikers te halen.

2 De aanbeveling van $10 \mathrm{E} \%$ is gebaseerd op het voorkomen van cariës .

A 1 en 2 zijn juist

B 1 en 2 zijn onjuist

C 1 is juist, 2 is onjuist

D 1 is onjuist, 2 is juist

(15) Welke van de volgende uitspraken is/zijn juist/onjuist?

1 Sorbitol en manitol zijn niet-calorische intensieve zoetstoffen (polyolen).

2 Glucose en fructose zijn monosachariden.

A 1 en 2 zijn juist

B 1 en 2 zijn onjuist

C 1 is juist, 2 is onjuist

D 1 is onjuist, 2 is juist

16 Welke van de volgende uitspraken is/zijn juist/onjuist?

1 De 'Friswijzer' geeft informatie over de hoeveelheid suiker in dranken in kcal.

2 De 'Friswijzer' geeft informatie over de hoeveelheid suiker in dranken, maar niet over het aanwezige zuur daarin.

A 1 en 2 zijn juist

B 1 en 2 zijn onjuist

C 1 is juist, 2 is onjuist

D 1 is onjuist, 2 is juist

17 Welke van de volgende uitspraken is/zijn juist/onjuist?

1 De Wet voedselinformatie eist dat alle voedingsstoffen op het etiket staan.

2 De Wet voedselinformatie eist dat behalve alle voedingsstoffen ook alle vitamines en mineralen op het etiket staan.

A 1 en 2 zijn juist

B 1 en 2 zijn onjuist

C 1 is juist, 2 is onjuist

D 1 is onjuist, 2 is juist

18 Welke van de volgende uitspraken is/zijn juist/onjuist?

1 Het blauwe Vinkje op de verpakking van voedingsmiddelen geeft aan dat een product gezond is.

2 Het Vinkje is een misleidend en verwarrend symbool op de verpakking van voedingsmiddelen.

A 1 en 2 zijn juist

B 1 en 2 zijn onjuist

C 1 is juist, 2 is onjuist

D 1 is onjuist, 2 is juist

(1) Welke van de volgende uitspraken is/zijn juist/onjuist?

1 Aroma's bepalen altijd de zuurgraad van voedingsmiddelen.

2 Alle E-nummers zijn ongezonde toevoegingen aan voedingsmiddelen.

A 1 en 2 zijn juist

B 1 en 2 zijn onjuist

C 1 is juist, 2 is onjuist

D 1 is onjuist, 2 is juist

Out of the Box: Etched retainers - door dr. Hans van Pelt

20 Welke van de volgende uitspraken is juist?

A Etched retainers zijn extracoronaire verankeringen ten behoeven van een frameprothese.

B Etched retainers kunnen ook conventioneel gecementeerd worden.

C Etched retainers zijn esthetisch fraaie oplossingen.

D Etched retainers moeten worden voorbehandeld in het laboratorium.

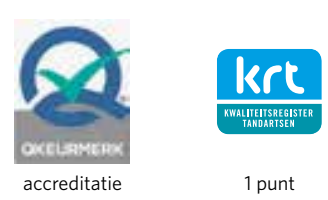

